\title{
Peningkatan Motif Berprestasi melalui Penerapan Konseling Kelompok pada Siswa Kelas XI IPS 4 SMA Negeri 11 Bandung
}

\section{Improvement of Achieving Motives through the Implementation of Group Counseling to Class XI IPS 4 Students of Senior High School 11 Bandung}

\author{
Sumarni \\ SMA Negeri 11 Bandung, Bandung, Jawa Barat, Indonesia \\ sumarnisebelas@gmail.com
}

\begin{abstract}
Abstrak
Penelitian ini bertujuan untuk mengetahui apakah pelaksanaan layanan Konseling kelompok dapat meningkatkan motif berprestasi siswa kelas XI IPS 4 SMA Negeri 11 Bandung dan memperoleh gambaran peningkatan motif berprestasi siswa XI IPS 4 setelah melaksanakan layanan konseling kelompok. Penelitian ini dilaksanakan di SMA Negeri 11 Bandung dengan subyek siswa kelas XI IPS 4 terdiri dari 39 siswa dengan jumlah 18 siswa laki laki dan 21 siswa perempuan. Para siswa ini menjadi siswa binaan karena memiliki motif berprestasi yang tegolong rendah. Teknik analisis data yang digunakanadalah analisis data kuantitatif untuk mengetahui tingkat motif berprestasi siswa. Sedangkan metode analisis data menggunakan analisis deskriptif persentase. Berdasarkan penelitian ditemukan bahwa pada Pra Penelitian rata rata pencapaian motif berprestasi siswa yang diperoleh $57,74 \%$, pada siklus I mengalami peningkatan rata rata pencapaian motif berprestasinya menjadi $71,79 \%$ dan pada siklus II rata rata pencapaian motif berprestasi mengalami peningkatan menjadi 78,45\%. Dari data tersebut terdapat peningkatan motif berprestasi siswa yang cukup signifikan dari siklus 1 ke siklus II yaitu sebesar 5,62\%. Maka dapat disimpulkan bahwa layanan konseling kelompok efektif untuk meningkatkan motif berprestasi yang dimiliki siswa kelas XI IPS 4 SMA Negeri 11 Bandung. Sebagai upaya lebih lanjut, pemetaan masalah yang dilakukan konselor harus lebih spesifik, sehingga persoalan-persoalan yang dialami siswa dapat teratasi melalui layanan konseling kelompok.
\end{abstract}

Kata kunci: motif berprestasi, penerapan konseling kelompok

\begin{abstract}
This research aims to determine whether the implementation of group counseling can improve the achievement motives of XI IPS 4 students at SMA Negeri 11 Bandung and obtain an overview of the increase in achievement motives of students of XI IPS 4 after implement it. This research was carried out in Senior High Schoo 11 Bandung with subjects of class XI IPS 4 consist of 39 students with 18 male students and 21 female students. These students become trained students because they have a low-achieving achievement motive. The data analysis technique used is quantitative data analysis to determine the level of student achievement motives. While the method of data analysis uses percentage descriptive analysis. Based on the research was founded that in the Pre-Study the average achievement of students' achievement motives obtained was $57.74 \%$, in the first cycle there was an increase in achievement achievement motives to $71.79 \%$ and in the second cycle the average achievement achievement motives had increased to 78.45 $\%$. From these data there is a significant increase in student achievement motives from cycle 1 to cycle II is $5.62 \%$. Then can be concluded that effective group counseling services to improve achievement motives possessed by students at Senior High Schoo 11 Bandung of class XI IPS4. Nextthe problem mapping by the counselor must be more specific, so that the students problems can be resolved through group counseling.
\end{abstract}

Keywords: achievement motives, application of group counseling 


\section{PENDAHULUAN}

Dewasa ini posisi pendidikan mendapat tempat yang strategis, dikatakan demikian karena pengembangan sumber daya manusia dengan modal dasar pembangunan sangat ditentukan oleh tingkat keberhasilan dalam bidang pendidikan. Sebuah kajian dari Bashiruddin (2016) tentang peran pendidikan pada pembangunan di negara Pakistan menjelaskan bahwa pendidikan telah mengisi celah dengan menganalisis efek dari semakin pentingnya pendidikan untuk sistem penghidupan pedesaan di wilayah GilgitBaltistan dan hal ini telah menarikperhatian banyak akademisi. Dalam Undang-Undang Nomor 20 Tahun 2003 tentang Sistem Pendidikan Nasional. Bab I ketentuan umum Pasal 1 menyebutkan sebagai berikut: "Pendidikan adalah usaha sadar dan terencana untuk mewujudkan suasana belajar dan proses pembelajaran agar peserta didik secara aktif mengembangkan potensi dirinya untuk memiliki kekuatan spiritual, keagamaan, pengendalian diri, kepribadian, kecerdasan, akhlak mulia serta keterampilan yang diperlukan dirinya, masyarakat, bangsa dan negara".

Sejalan dengan undang-undang tersebut, dalam permendiknas no 23 Tahun 2006 dirumuskan SKL yang harus dicapai peserta didik melalui proses pembelajaran bidang studi. Kompetensi peserta didik yang dikembangkan melalui layanan Bimbingan dan Konseling adalah kompetensi kemandirian untuk mewujudkan diri (Self Actualization) dan pengembangan kapasitasnya (capacity development) yang dapat mendukung pencapaian kompetensi lulusan tersebut. Hal ini sebagaimana menurut Irham dan Wiyana
(2014) bahwa tujuan bimbingan dan konseling secara umum adalah membantu peserta didik mengembangkan diri secara optimal sesuai 13 dengan tahap perkembangan, potensi, latar belakang yang dimilki, dan tuntutan kondisi zaman”. Di sisi lain kesuksesan peserta didik dalam SKL akan secara signifikan menunjang terwujudnya pengembangan kemandirian. Untuk mencapai tujuan tersebut guru dituntut untuk berupaya agar mampu menciptakan proses belajar mengajar dalam suasana pembelajaran yang baik, agar pengajaran dapat berlangsung dengan baik.

Wulandari (2013) mengemukakan bahwa dalam pelaksanaan bimbingan dan konseling seringkali ditemukan beberapa hambatan di antaranya hambatan internal yaitu komponen kompetensi sosial dan hambatan eksternal berupa peran siswa, sarana dan prasarana, dan administrasi BK. Sari dkk (2008) mengemukakan bahwa faktor penghambat ketidak sesuaian program-program bimbingan dan konseling dengan aspek-aspek dasar penyusunan program bimbingan dan konseling, keterbatasan sarana prasarana, ketidaksesuaian latar belakang pendidikan guru bimbingan dan konseling dan Kurangnya kerja sama antar personalia pelaksanaan layanan bimbingan dan konseling di sekolah. Dalam praktiknya penangan masalahmasalah siswa dalam kerangka Bimbingan dan Konseling sangat ditentukan oleh kerja sama yang harmonis dengan seluruh personil sekolah, baik Kepala Sekolah,Wali kelas, guru mata pelajaran, guru bidang studi, serta keterampilan pembimbing dalam melaksanakan berbagai layanan yaitu sesuai dengan empat fungsi layanan Bimbingan dan Konseling yaitu: fungsi pemahaman, fungsi 
pencegahan, fungsi pengentasan dan fungsi pemeliharaan, serta fungsi pengembangan (Sukardi, 2000). Keempat fungsi tersebut harus terintegrasi dengan baik sehingga akan membantu berjalannya seluruh sistem yang ada di sekolah terutama proses pembelajaran.

Dari hasil pengamatan, permasalahan yang timbul pada siswa siswi SMA Negeri 11 Bandung kelas XI IPS 4 ditunjukkan dengan kekurangsiapan siswa dalam belajar seperti datang terlambat, tidak masuk sekolah dan tugas-tugas pelajaran yang tidak dikerjakan secara optimal, dan dalam kegiatan belajar mengajar di kelas tidak ada keinginan untuk bertanya atau mengemukakan pendapat. Permasalahan yang telah dipaparkan berpengaruh terhadap hasil belajar yang diperoleh para siswa. Hal ini terlihat dalam laporan tengah semester yang menjelaskan bahwa hampir $60 \%$ siswa harus mengikuti remedial.

Salah satu upaya yang dapat dilakukan guru bimbingan dan konseling adalah dengan menyelenggarakan konseling kelompok. Layanan konseling kelompok merupakan suatu upaya remedial saat membahas topik atau isu-isu seputar hal-hal yang mengganggu atau menghambat proses belajar dan perkembangan kelompok siswa tertentu (Rusmana, 2009). Melalui layanan konseling kelompok, guru bimbingan dan konseling dapat membantu siswa menyelesaikan persoalan-persoalan yang berkaitan dengan aspek akademik atau belajar, sehingga motif berprestasi siswa dapat ditingkatkan dan prestasi belajarnya dapat tercapai secara optimal. Kurnanto (2013) juga mengemukakan bahwa dengan konseling kelompok individu mencapai tujuannya dan dapat berhubungan dengan yang lainnya dengan cara yang inovatif dan produktif. Sebuah penelitian dari Fiah \& Anggralisa (2016) menunjukkan bahwa layanan konseling kelompok dengan teknik realita yang dilaksanakan secara intensif dapat efektif mengatasi kesulitan komunikasi interpersonal khususnya pada peserta didik. Wikarta (2016) menemukan bahwa bimbingan konseling kelompok dengan pendekatan Person Centered Therapy berhasil meningkatkan motif para anggota kelompok untuk memperbaiki prestasi belajar dan kinerja dalam proses belajar, tetapi di sisi lain pendekatan ini kurang berhasil mengubah perilaku subjek penelitian untuk melakukan regulasi diri dalam waktu yang singkat.

Adapun penelitian ini berangkat dari fenomena akademik siswa yang kurang optimal. Sebagian siswa mengalami kendala dalam proses pembelajarannya, sehingga prestasi akademik yang diraihnya tidak optimal. Untuk itu diperlukan usaha penanganan tidak hanya oleh siswa itu sendiri, tetapi juga dari pihak luar dalam hal ini orang tua dan pihak sekolah. Untuk menangani masalah ini, peneliti menggunakan layanan konseling kelompok karena menurut peneliti siswa dapat bersama-sama berbagi alternatifalternatif yang dapat diaplikasikan anggota kelompok, dapat melatih keberanian siswa untuk mengemukakan pendapat dan bertanya kepada guru/teman serta dapat digunakan untuk membantu siswa dalam rangka mengaplikasikan alternatif-alternatif dalam peningkatan motivasi belajar. Berdasarkan uraian tersebut, penulis tertarik untuk melakukan penelitian tindakan bimbingan konseling tentang peningkatan motif berprestasi dengan judul "Peningkatkan Motif 
Berprestasi melalui Penerapan Konseling Kelompok pada Siswa Kelas XI IPS 4 SMA Negeri 11 Bandung".

\section{METODE PENELITIAN}

\section{Metode Penelitian}

Metode yang digunakan dalam kegiatan ini adalah penelitian tindakan bimbingan konseling yaitu suatu kajian reflektif yang dilakukan konselor dalam meningkatkan kemampuan berpikir secara rasional dan bertindak untuk memperbaiki kualitas bimbingannya terhadap peserta didik. Model yang digunakan adalah model Kurt Lewin yang terdiri atas empat komponen yaitu: perencanaan (planning), tindakan (acting), pengamatan (observing), dan refleksi (reflecting).

\section{Prosedur Penelitian}

Penelitian Tindakan ini melibatkan guru BK dan wali kelas yang bertujuan untuk membantu memecahkan masalah yang dihadapi siswa. Dalam pelaksanaan Penelitian Tindakan Bimbingan Konseling ini dirancang 2 (dua) siklus.

\section{Waktu Dan Tempat Penelitian}

Penelitian tindakan bimbingan dan konseling ini dilaksanakan selama 5 bulan pada semester 2 yaitu dari bulan Januari sampai dengan Mei 2018 di kelas XI IPS 4 SMA Negeri 11 Bandung Tahun Pelajaran 2017/2018 yang berlokasi di Kembar Baru
23 Bandung 40253.

\section{Subjek penelitian}

Subjek penelitian ini siswa kelas XI IPS 4 dengan jumlah 39 siswa terdiri dari 18 siswa laki laki dan 21 siswa perempuan. Para siswa ini menjadi siswa binaan karena memiliki motif berprestasi yang tegolong rendah.

\section{Instrumen Penelitian}

Instrumen yang digunakan dalam penelitian ini yaitu Rencana Program Layanan (RPL) disusun sebagai pedoman bagi konselor dalam kegiatan layanan, angket motif berprestasi disusun untuk mendapatkan informasi atau keterangan dari sumber data (responden), pedoman observasi konselor dan siswa disusun untuk memperoleh gambaran langsung saat kegiatan layanan.

\section{Teknik Pengumpulan Data}

Teknik pengumpulan data penelitian bimbingan dan konseling dilakukan dengan berdasarkan:Sumber data, jenis data, teknik pengumpulan data, Instrumen yang digunakan.

Teknik analisis data yang digunakan yaitu analisis data kuantitatif, yaitu skala untuk mengetahui tingkat motif berprestasi siswa. Skala motif berprestasi berupa skala likert. Dengan presentase hasil motif berprestasi $\operatorname{skor}(s)=\frac{\text { jumlah skor tiap subyek }}{\text { skor } \text { ideal }} \times 100 \%$ kriteria sebagai berikut :

Tabel 1. Kriteria Tingkat Motif Berprestasi

\begin{tabular}{ccc}
\hline No & Kriteria & Presentase \\
\hline 1 & Tinggi & $76 \%-100 \%$ \\
\hline 2 & Sedang & $51 \%-75 \%$ \\
\hline 3 & Rendah & $26 \%-50 \%$ \\
\hline 4 & Rendah sekali & $<25 \%$ \\
\hline
\end{tabular}


Penelitian dikatakan cukup apabila mencapai kategori baik/tinggi dalam tingkat motif berprestasinya, atau nilai motivasi belajar siswa dalam kelas mencapai 76\%, tetapi jika belum mencapai skor yang diharapkan akan dilanjutkan ke siklus selanjutnya (kedua).

\section{HASIL DAN PEMBAHASAN}

\subsection{Hasil Penelitian}

\section{Gambaran Motif Berprestasi Siswa Pra Penelitian}

Gambaran umum motif berprestasi siswa kelas XI IPS 4 yang diungkap melalui angket motif berprestasi didapatkan data bahwa tingkat rata-rata motif berprestasi siswa secara keseluruhan adalah $57,74 \%$, hal ini menunjukan bahwa tingkat motif berprestasi siswa kelas XI IPS 4 berada dalam kategori sedang, namun demikian berdasarkan angka tersebut dapat dilihat bahwa pencapaian motif berprestasi yang dimiliki siswa belum optimal. Lebih lanjut pemetaan dari sebaran data motif berprestasi siswa secara individual disusun dan diolah untuk memperoleh kriteria pada tabel 2 berikut ini.

Tabel 2. Gambaran motif berprestasi siswa Pra Penelitian

\begin{tabular}{clcc}
\hline No & Pencapaian & Hasil Pengamatan & Jumlah Skor \\
\hline 1 & Nilai Tertinggi & $74,43 \%$ & 131 \\
\hline 2 & Nilai Terendah & $43,75 \%$ & 77 \\
\hline 3 & Rata rata & $57,74 \%$ & 102 \\
\hline
\end{tabular}

Berdasarkan data tabel 2 tentang sebaran data motif berprestasi, secara rinci dapat terlihat bahwa dari 39 siswa kelas XI IPS 4 yang menjadi responden menunjukkan motif berprestasi sedang yang secara ratarata dimiliki oleh siswa sebesar 57,74\%. Sedangkan yang paling rendah ditunjukkan oleh siswa yang memiliki nilai sebesar $43,75 \%$ dan yang paling tinggi memiliki nilai sebesar 74,43\%. Hasil data awal yang dikumpulkan menjadi dasar dalam perancangan dan pelaksanaan tindakan kelas layanan bimbingan dan konseling dengan tujuan untuk mengembangkan kemampuan siswa dalam menyikapi motif berprestasi rendah dengan tepat.

\section{Tahapan dan Temuan Hasil Konseling Kelompok Siklus-I}

\section{a. Tahap perencanaan}

Kegiatan awal dilakukan pada hari kamis tanggal 11 Januari 2018 jam ke-2.
1) Sebelum menyusun RPL, peneliti melakukan identifikasi masalah dan merencanakan langkah-langkah yang akan dilaksanakan pada siklus I.

1) Setelah peneliti mengetahui masalah dan langkah-langkah yang akan dilaksanakan pada tindakan di siklus I, peneliti kemudian membuat RPL.

2) Menentukan pokok bahasan yang akan dijadikan materi bahasan pada penelitian.

3) Mengembangkan RPL.

4) Mengembangkan format evaluasi.

5) Mengembangkan format observasi pembelajaran.

\section{b. Tahap pelaksanaan}

Layanan konseling kelompok pada siklus-1 dilaksanakan dalam dua kali pertemuan yaitu

1) Pelaksanaan kegiatan layanan pada pertemuan pertama

Hari / Tanggal : kamis / 11 Januari 2018 jam ke-2. 
a) Konselor terlebih dahulu mengamati tingkat kesiapan siswa dalam pelaksanaan kegiatan, mengecek absensi siswa serta mengondisikan kelas agar kegiatan dapat berlangsung secara kondusif.

b) Memberikan apersepsi dan penghargaan dengan tanya jawab tentang materi yang akan diajarkan.

c) Konselor menjelaskan materi secara singkat tentang motif berprestasi.

d) konselor menjelaskan materi dengan memberikan contoh-contoh yang terjadi secara keseharian di lingkungan kelas dan belajar di sekolah.

e) konseor mengkondisikan kelas untuk membentuk kelompok menjadi 4 kelompok.

f) Tiap kelompok melakukan konseling kelompok dengan mengungkapkan pemahaman dan permasalahan sesuai dengan materi yang telah disampaikan.

2) Pelaksanaan kegiatan layanan pada pertemuan kedua

Hari / Tanggal : kamis / 18 Januari 2018 jam ke-2.

a) Konselor terlebih dahulu mengamati tingkat kesiapan siswa dalam pelaksanaan kegiatan, mengecek absensi siswa serta mengondisikan kelas agar kegiatan dapat berlangsung secara kondusif.

b) Konselor kembali memberikan apersepsi dan penghargaan dengan tanya jawab tentang materi yang akan diajarkan.

c) Konselor menjelaskan materi secara singkat tentang motif berprestasi.

d) konselor menjelaskan materi dengan memberikan contoh-contoh yang terjadi secara keseharian di lingkungan kelas dan belajar di sekolah.

e) konselor mengkondisikan kelas untuk membentuk kelompok menjadi 4 kelompok. Tiap kelompok melakukan konseling kelompok dengan mengungkapkan pemahaman dan permasalahan sesuai dengan materi yang telah disampaikan.

c. Tahap pengamatan

Dari hasil observasi siklus I, didapatkan bahwa dalam melaksanakan kegiatan meningkatkan motif berprestasi dengan menggunakan teknik konseling kelompok pada siklus I, konselor telah menerapkannya sesuai dengan Rencana Program Layanan (RPL) yang telah disiapkan. Berdasarkan hasil pengamatan yang dilakukan oleh observer, konselor kurang menguasai kelas pada saat mengkondisikan/membagi kelas menjadi empat kelompok, sehingga masih ada siswa yang terlambat memahami apa yang harus dilakukan pada saat kegiatan konseling kelompok tersebut. Masalah lain yang didapat dari pengamatan observer adalah pada saat menjelaskan materi motif berprestasi, masih ada siswa yang kurang memperhatikan. Data mengenai keaktifan siswa dapat diperoleh dengan menggunakan lembar observasi seperti pada lampiran. Keaktifan siswa tersebut dapat dilihat dalam hal bertanya maupun antusiasnya dalam mengikuti pembelajaran. Data mengenai aktifitas siswa pada siklus I menunjukkan bahwa sebagian besar siswa kurang antusias 
mengikuti kegiatan layanan bimbingan dan konseling tersebut.

Berdasarkan hasil penelitian tindakan bimbingan dan konseling siklus I, masih perlu dilakukan peningkatan dalam hal pelaksanaan penelitian. Hal ini disebabkan pada pelaksanaan siklus pertama sebagian besar siswa masih kurang antusias mengikuti kegiatan penelitian tindakan bimbingan dan konseling, sehingga hasil yang dicapai belum sesuai yang diharapkan. Antusiasme yang kurang dari siswa disebabkan beberapa faktor, diantaranya kondisi psikologis siswa yang sudah lelah, karena pelaksanaan pengambilan data awal dilakukan menjelang jam terakhir pelajaran, sehingga siswa sudah mulai jenuh. Faktor selanjutnya adalah, konselor kurang mempersiapkan kemungkinan-kemungkinan yang terjadi di dalam kelas, sehingga kelas kurang terkoordinir dengan baik.

Berdasarkan kondisi yang terjadi pada pelaksanaan siklus I, terdapat beberapa hal yang harus segera diperbaiki oleh konselor dalam pelaksanaan penelitian ini. Adapun hal-hal yang harus dievaluasi diantaranya:

1) Konselor perlu meninjau ulang waktu pelaksanaan penelitian tindakan bimbingan dan konseling, sehingga kondisi psikologis siswa pada saat penelitian dalam keadaan fresh.

2) Konselor perlu mempersiapkan teknikteknik yang lebih menarik, sehingga siswa lebih antusias dalam mengikuti kegiatan penelitian tindakan bimbingan dan konseling.

3) Konselor kurang memotivasi siswa

Untuk mengetahui besaran motif berprestasi siswa, maka pada akhir siklus I diberikan kembali kuesioner motif berprestasi siswa dan hasilnya dapat dilihat pada tabel 3 berikut.

Tabel 3. Data Hasil Skor Motif berprestasi siswa Kelas XI IPS 4 siklus I

\begin{tabular}{clcc}
\hline No & \multicolumn{1}{c}{ Pencapaian } & Hasil Pengamatan & Jumlah Skor \\
\hline 1 & Nilai Tertinggi & $77,84 \%$ & 137 \\
\hline 2 & Nilai Terendah & $66,48 \%$ & 117 \\
\hline 3 & Rata rata & $71,79 \%$ & 128 \\
\hline
\end{tabular}

Berdasarkan tabel 3 diperoleh rata-rata nilai siswa dalam persentase sebesar $71,79 \%$, kemudian persentase nilai tinggi sebesar $77,84 \%$ dan persentase nilai terendah sebesar $66,48 \%$. Hal ini memberikan gambaran bahwa terjadi peningkatan motif berprestasi siswa dari pra siklus/pre-test ke siklus I. Namun, peningkatan yang terjadi belum sesuai dengan harapan peneliti, sehingga perlu dilaksanakan konseling kelompok yang lebih intensif pada siklus selanjutnya.

\section{d. Tahap refleksi}

Berdasarkan analisis data di atas, masih terdapat kekurangan-kekurangan pada siklus I. Kekurangan-kekurangan tersebut antara lain konselor kurang dapat mengkondisikan kelas pada saat siswa membentuk kelompok sehingga memakan waktu yang lebih banyak. Akibatnya masih ada siswa yang kurang memperhatikan kegiatan. Dengan adanya kekurangan-kekurangan tersebut, maka perlu adanya perbaikan-perbaikan dalam RPL untuk siklus II. Perbaikan tersebut yaitu dengan cara konselor harus lebih dapat mengkondisikan siswa, sehingga siswa benar-benar terlibat dalam Kegiatan layanan bimbingan dan konseling. 


\section{Temuan hasil konseling kelompok} siklus II

Penelitian tindakan bimbingan dan konseling pada siklus kedua dilaksanakan melalui konseling kelompok pada hari kamis tanggal 25 Januari 2018 jam ke-2 dengan tahapan sebagai berikut.

\section{a. Tahap perencanaan}

Siklus kedua dibagi menjadi dua pertemuan, pertemuan pertama konseling kelompok berisikan mengenai pemahaman diri akan penyebab lemahnya motif berprestasi yang dimiliki dan solusinya dan pertemuan kedua materi berisikan bagaimana pengalaman diri tentang bagaimana menangani motif berprestasi yang lemah hasil dari pertemuan pertama. Pertemuan pertama pada siklus II dilakukan pada hari kamis 25 Januari 2018 jam ke-2, dengan rencana sebagai berikut:

1) Setelah peneliti mengetahui masalah dan langkah-langkah yang akan dilaksanakan pada tindakan di siklus II, peneliti kemudian membuat Rencana Program Layanan (RPL) dan mengembangkannya berdasarkan evaluasi dari siklus I.

1) Karena sudah terbagi kelompok pada siklus I, maka siklus II keadaan kelas sudah berkelompok seperti pada siklus I.

2) Siklus II dilakukan melalui dua pertemuan, pertemuan pertama membahas mengenai Pemahaman diri akan hambatan-hambatan yang menyebabkan kurangnya motif berprestasi.

3) Dengan konseling kelompok mencati solusi setiap hambatan-hambatan yang dimiliki siswa.

4) Pemberian tugas mengenai motif berprestasi.
Pertemuan kedua pada siklus II dilakukan pada hari kamis 1 Februari 2018.

1) Kelas sudah dalam bentuk kelompok pada saat dimulainya pertemuan kedua pada siklus II.

2) Tiap kelompok membahas mengenai tugas hasil dari pertemuan pertama bersama dengan solusi.

3) Refleksi dari konselor mengenai hambatan-hambatan motif berprestasi dan bagaimana cara mengatasi setiap permasalahan yang dihadapi dalam belajar.

\section{b. Tahap Pelaksanaan}

1) Pelaksanaan kegiatan layanan pada pertemuan pertama, Kamis 25 Januari 2018

a) Konselor terlebih dahulu meneliti tingkat kesiapan siswa, mengecek absensi siswa serta mengondisikan kelas agar kegiatan dapat berlangsung secara kondusif.

b) Karena kelas sudah terbagi ke dalam 4 kelompok absensi dilakukan perkelompok.

c) Melakukan apersepsi dengan tanya jawab tentang materi yang sudah diberikan pada siklus I dan materi yang akan disampaikan.

d) Tiap kelompok melakukan konseling kelompok berdasarkan materi yang telah disampaikan.

2) Pelaksanaan kegiatan layanan pada pertemuan kedua, Kamis 1 Februari 2018

a) Konselor terlebih dahulu meneliti tingkat kesiapan siswa, mengecek absensi siswa serta mengondisikan kelas agar kegiatan dapat berlangsung secara kondusif. 
b) Karena kelas sudah terbagi ke dalam 4 kelompok absensi dilakukan perkelompok.

c) Melakukan apersepsi dengan tanya jawab tentang materi yang sudah diberikan pada pertemuan pertama dan kegiatan yang akan dilakukan.

d) Tiap kelompok melakukan konseling kelompok berdasarkan tugas yang diberikan pada pertemuan pertama dan bagaimana solusinya.

e) Tiap kelompok mencatat mengenai permasalahan yang ditemukan dan bagaimana solusinya.

f) Konselor mengumpulkan catatan dari tiap kelompok dan melakukan pembahasan secara bersama.

g) Refleksi dari konselor mengenai materi dimulai dari siklus I dan siklus II (pertemuan pertama dan kedua). Menarik kesimpulan secara bersama atas kegiatan layanan bimbingan dan kelompok tersebut.

\section{c. Tahap pengamatan}

Hasil observasi siklus II yang dilaksanakan oleh para siswa terdapat beberapa kekurangan didapatkan, diantaranya: siswa kurang fokus pada saat konseling kelompok baik pada pertemuan pertama maupun pertemuan kedua, kemungkinan waktu yang terlalu lama pada saat konseling kelompok terlihat beberapa siswa yang merasa jenuh dan kurang ikut terlibat dalam konseling kelompok. Data mengenai keaktifan siswa dapat diperoleh dengan menggunakan lembar observasi seperti pada tabel 4. Keaktifan siswa tersebut dapat dilihat dalam hal bertanya maupun antusiasnya dalam mengikuti pembelajaran. Data mengenai aktifitas siswa pada siklus II menunjukkan 10 siswa kurang antusias mengikuti Kegiatan layanan bimbingan dan konseling tersebut. Seperti halnya pada siklus I, pelaksanaan siklus II masih terdapat beberapa kekurangan. Hal yang paling mempengaruhi antusiasme siswa dalam mengikuti kegiatan ini adalah pengelolaan waktu kegiatan yang terlalu lama, sehingga menurunkan antusiasme siswa. Untuk mengetahui besaran motif berprestasi siswa, maka pada akhir siklus II diberikan kembali kuesioner motif berprestasi siswa dan hasilnya dapat dilihat pada tabel 4 berikut.

Tabel 4. Data Hasil Skor Motif berprestasi siswa Kelas XI IPS 4 siklus II

\begin{tabular}{clcc}
\hline No & \multicolumn{1}{c}{ Pencapaian } & Hasil Pengamatan & Jumlah Skor \\
\hline 1 & Nilai Tertinggi & $84,66 \%$ & 149 \\
\hline 2 & Nilai Terendah & $73,86 \%$ & 130 \\
\hline 3 & Rata rata & $78,45 \%$ & 138 \\
\hline
\end{tabular}

Berdasarkan tabel 4. terlihat bahwa ratarata nilai siswa $78,45 \%$ dengan nilai tertinggi $84,66 \%$ dan nilai terendah $73,86 \%$. Hal ini memberikan gambaran bahwa secara ratarata terdapat peningkatan motif berprestasi siswa dari siklus I ke siklus II. Peningkatan yang terjadi merupakan akumulasi dari pelaksanaan konseling kelompok dari siklus I hingga siklus II. Oleh karena itu, untuk menjaga motif berprestasi siswa agar tetap pada kemampuannya sekarang, perkembangan siswa perlu terus dipantau.

\section{d. Tahap refleksi}

Berdasarkan analisis data di atas, masih 
terdapat kekurangan-kekurangan pada siklus II. Kekurangan-kekurangan dalam siklus I sudah mulai tertutupi dikarenakan untuk siklus II ini para siswa sudah memiliki persiapan untuk kegiatan layanan. Kekurangan konselor, konselor kurang dapat mengkondisikan kelas pada saat siswa membentuk kelompok sehingga memakan waktu yang lebih banyak. Akibatnya masih ada siswa yang kurang memperhatikan kegiatan. Dengan adanya kekurangankekurangan tersebut, maka perlu adanya perbaikan-perbaikan RPL untuk siklus II. Perbaikan tersebut yaitu dengan cara konselor harus lebih dapat mengkondisikan siswa, sehingga siswa benar-benar terlibat dalam Kegiatan layanan bimbingan dan konseling.

Walaupun terdapat beberapa kekurangan, peneliti merasa pemberian layanan konseling kelompok sangat efektif untuk meningkatkan motif berprestasi siswa. Hal tersebut sejalan dengan hasil pre testpost test yang dilakukan menunjukkan peningkatan. Peningkatan seperti ini cukup membanggakan bagi peneliti, karena selama proses pemberian layanan konseling individual, peneliti mengalami beberapa hambatan.

\subsection{Pembahasan}

Motivasi berprestasi merupakan daya penggerak yang memotivasi semangat bekerja seseorang, yang mendorong seseorang untuk mengembangkan kreativitas dan menggerakkan semua kemampuan serta energi yang dimilikinya demi mencapai prestasi kerja yang maksimal (Djamarah, 2012). Motivasi berprestasi merupakan suatu kebutuhan untuk memberikan prestasi yang mengungguli standar. menantang tanggung jawab secara pribadi dan terbuka untuk umpan balik guna memperbaiki prestasi inovatif-kreatifnya. Adanya motivasi berprestasi membuat seseorang mengerahkan seluruh kemampuannya untuk menjalankan semua kegiatan yang sudah menjadi tugas dan tanggung jawabnya untuk mencapai target-target tertentu yang harus dicapainya pada setiap satuan waktu. Individu tersebut menyukai tugas-tugas yang mempertahankan kecakapan diri setinggi mungkin dalam semua aktivitas dengan menggunakan standar keunggulan sebagai pembanding. Standar keunggulan yang dimaksud adalah berupa prestasi orang lain atau prestasi sendiri yang pernah diraih sebelumnya.

Bimbingan konseling merupakan upaya pemberian bantuan yang dirancang dengan menfokuskan pada kebutuhan, kekuatan minat, isu-isu yang berkaitan dengan tahapan perkembangan anak termasuk motivasi berprestasi siswa. Ngalimun (2014) menyatakan bahwa tujuan bimbingan dan konseling yang merujuk kepada perkembangan individu ialah membantu agar tercapai tahap perkembangannya secara optimal.

Adapun teknik bimbingan konseling dalam penelitian ini adalah layanan bimbingan dan konseling kelompok. Prayitno \& Amti (2004) mendefinisikan layanankonselingkelompoksebagailayanan konseling perorangan yang dilaksanakan didalam suasana kelompok. Arifin (2015) mendefinisikan konseling kelompok sebagai konseling yang diselenggarakan dalam kelompok dengan memanfaatkan 
dinamika kelompok yang terjadi dalam kelompok itu. Lebih lanjut Wibowo (2005) memaparkan bahwa konseling kelompok memiliki kekuatan yang tidak dimiliki oleh jenis layanan lain, yaitu Kepraktisan, dapat digunakan sebagai ajang latihan untuk mengubah perilaku yang kurang memuaskan, kesempatan berkomunikasi dalam konseling kelompok lebih luas, memberikan kesempatan pada para anggota untuk mempelajari keterampilan sosial, anggota kelompok mempunyai kesempatan untuk saling membantu dan berempati dengan tulus, tingkat transfer pelatihan dalam konseling kelompok lebih tinggi, mempunyai manfaat besar untuk bertindak sebagai miniatur situasisosial, individu dapat mencapai tujuannya dan berhubungan dengan individu yang lain dengan produktif dan inovatif, konseli dapat mengambil manfaat dari umpan balik yang diberikan konseli lain, interaksi antar individu dalam konseling kelompok adalah sesuatu yang khas dan konseling kelompok dapat menjadi wadah bagi penjajakan awal konseli sebelum masuk ke dalam konseling individual. Maka adari itu, layanan bimbingan konseling ini diharapkan dapat menumbuhkembangkan motif berprestasi dalam diri (motif internal) peserta didik karena motif internal merupakan faktor yang sangat membantu dan sangat menentukan dalam pencapaian prestasi seseorang.

\section{Peningkatan Motif Berprestasi Siswa Kelas XI IPS 4}

Penelitian tindakan ini meliputi dua siklus, setiap siklus terdiri dari tahap perencanaan, tahap pelaksanaan, tahap pengamatan dan tahap refleksi. Data hasil penelitian ini diperoleh dari hasil evaluasi diakhir tiap siklus yang dilakukan oleh observer dan konselor selama proses kegiatan layanan berlangsung, baik pada siklus I maupun siklus II. Penelitian dikatakan cukup apabila mencapai kategori baik/tinggi dalam tingkat motif berprestasinya jika mencapai $76 \%$. Data pencapain presentase untuk setiap siklus dapat dilihat pada tabel 5 dan gambar 1

Tabel 5. Data Hasil Skor Motif berprestasi Siswa Kelas XI IPS 4

Pra Penelitian, siklus I dan Siklus II

\begin{tabular}{llccc}
\hline \multirow{2}{*}{ No } & \multirow{2}{*}{ Pencapaian } & \multicolumn{3}{c}{ Hasil Pengamatan } \\
\cline { 3 - 5 } & & Pra Penelitian & Siklus I & Siklus II \\
\hline 1 & Nilai Tertinggi & $74,43 \%$ & $77,84 \%$ & $84,66 \%$ \\
\hline 2 & Nilai Terendah & $43,75 \%$ & $66,48 \%$ & $73,86 \%$ \\
\hline 3 & Rata rata & $57,74 \%$ & $71,79 \%$ & $78,45 \%$ \\
\hline
\end{tabular}

Adapun Dalam kegiatan kelompok yang ditampilkan oleh seluruh anggota kelompok adalah: (a) membina keakraban dalam kelompok, (b) melibatkan diri secara penuh dalam suasana kelompok, (c) bersama-sama mencapai tujuan kelompok, (d) membina dan mematuhi aturan kegiatan kelompok, (e) ikut serta dalam seluruh kegiatan kelompok, (f) berkomunikasi secara bebas dan terbuka, (g) membantu anggota lain dalam kelompok, (h) memberikan kesempatan anggota lain dalam kelompok, (i) menyadari pentingnya kegiatan kelompok. Berikut data pencapaian presentase untuk setiap siklus: 


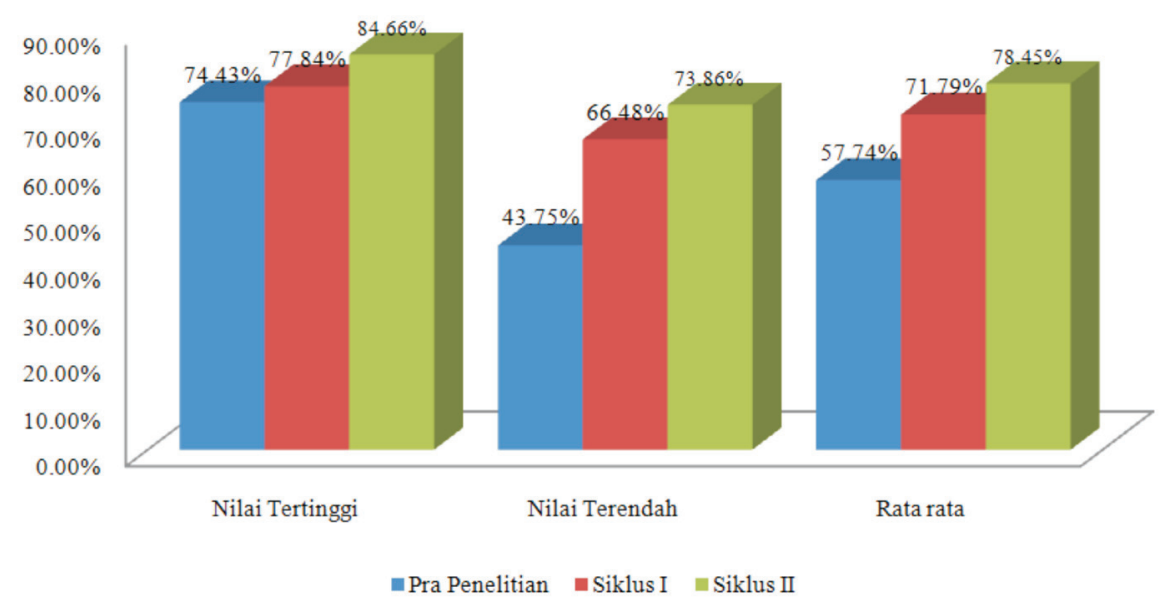

Gambar 1. Data Hasil Skor Motif berprestasi Siswa Kelas XI IPS 4 Pra Penelitian siklus I dan Siklus II

Berdasarkan hasil Pra Penelitian rata rata pencapaian motif berprestasi siswa yang diperoleh adalah 57,74\% artinya tingkat motivasinya sedang, dengan presentase nilai tertinggi $74,43 \%$ dan presentase nilai terendah $43,75 \%$ hasil data awal ini dijadikan dasar untuk melakukan tindakan bimbingan konseling.

a. Analisis Tindakan Siklus I

Presentase hasil belajar pada siklus I nilaitertinggi $77,84 \%$, presentase nilai terendah $66,48 \%$ dan presentase nilai hasil belajar rata rata yang diperoleh adalah $71,79 \%$, artinya belum mencapai presentase nilai yang diharapkan yaitu $76 \%$ sehingga penelitian tindakan bimbingan konseling pada siklus I belum berhasil.

\section{b. Analisis Tindakan Siklus II}

Presentase hasil belajar pada siklus II mengalami peningkatan yaitu dengan naiknya presentase rata rata kelas menjadi $78,45 \%$ sedangkan nilai tertinggi $84,66 \%$ dan nilai terendah $73,86 \%$. Rata rata secara klasikal telah memenuhi kriteria yang ditentukan yaitu $76 \%$, sehingga penelitian tindakan pada siklus II ini telah berhasil. Rata rata presentase nilai meningkat dari siklus I ke Siklus II sebesar 5,62\%.

\section{Gambaran Peningkatan Motif Berprestasi Siswa Kelas XI IPS4}

Gambaran peningkatan kegiatan layanan konseling kelompok yang telah diberikan pada siswa kelas XI IPS 4 dapat dikatakan bahwa ternyata masih banyak siswa yang belum mengetahui sebenarnya bentuk konseling kelompok itu seperti apa dan bagaimana pengaruh dan manfaatnya bagi diri dan teman sekelompoknya mengenai pembahasan permasalahan yang dilakukan secara berkelompok tersebut.

Pada saat konseling kelompok berjalan maka peneliti mengamati berdasarkan format observasi yang sudah disiapkan, beserta tambahan-tambahan lain yang tidak terdapat dalam format observasi, diantaranya:

1) Siapa saja siswa yang aktif dalam kelompoknya.

2) Siswa yang cenderung pasif dalam kelompoknya.

3) Keberanian mengenai masalah motif yang dialaminya.

4) Kebersediaan untuk mendengarkan permasalahan anggota kelompok lain. 
5) Kecenderungan dalam memberikan komentar terhadap permasalahan yang dihadapi oleh anggota kelompok yang lain.

6) Ternyata masih banyak siswa yang masih kurang percaya diri untuk mengungkapkan pendapat dan permasalahannya dalam kelompok.

Terdapat perkembangan antara siklus II dengan siklus I kemungkinan dikarenakan bahwa pada siklus II para siswa sudah memahami mengenai kegiatan yang dilakukan. Dibuktikan dengan aktifitas siswa selama kegiatan yang terlihat lebih berani dalam mengungkapkan pendapatnya kepada kelompok dan juga berani dalam menjawab pertanyaan yang diberikan oleh kelompok kepada dirinya hal tersebut terjadi pada hampir pada semua anggota kelompok. Selain itu, keberhasilan ini pun tidak terlepas dari faktor kesiapan pengajar atau guru. Irham dan Wiyana (2014) menyebutkan bahwa kesiapan guru tersebut di antaranya kesiapan program sejak awal tahun pembelajaran dan personel sekolah lainnya mengetahui dengan jelas programprogram tersebut.

Pengamatan peneliti kepada siswa pun tidak sebatas itu pada kegiatan belajar mereka di kelas pun memiliki peningkatan positif seperti tugas-tugas dan juga tingkat kehadiran yang meningkat dan keterlambatan yang semakin berkurang. Sehingga dalam hal ini konseling kelompok tepat diberikan kepada para siswa khususnya siswa XI IPS 4dalam meningkatkan motif berprestasi siswa.

\section{Dampak penerapan layanan konseling kelompok}

Sebelum diberikannya layanan konseling kelompok siswa memiliki motif yang lemah terhadap belajar seperti malas dalam mengerjakan PR, sering terlambat, takut pada guru, terlalu sering menonton acara televisi, tidak mau membaca buku pelajaran kembali sepulangnya dari sekolah. Setelah diberikan layanan bimbingan dan konseling kelompok sebanyak 2 siklus 2 kali pertemuan menunjukkan perubahan yang signifikan, motif berprestasi siswa mulai meningkat yang sebelumnya pendiam dan biasa-biasa saja di kelas menjadi lebih percaya diri dan memiliki motif berprestasi yang kuat begitu juga yang sudah memiliki motif yang tinggi dalam belajar hanya tinggal mempertahankannya.

Peningkatan motif berprestasi ini terjadi dikarenakan kefektifitasan pemberian layanan konseling kelompok yang dilakukan sesuai prosedur, sehingga tujuan penelitian dapat tercapai. Hasil penelitian pun sejalan dengan pendapat Rusmana (2009) yang menyatakan konseling kelompok memberikan forum yang tepat bagi pembelajaran siswa-ke-siswa semacam ini. berhubungan dengan hal ini, kekuatan dari kelompok sebaya dapat meningkatkan pertumbuhan dan perkembangan yang positif dibawah kepemimpinan yang terampil dari konselor sekolah profesional.

\section{SIMPULAN}

Dari hasil penelitian yang menunjukan adanya peningkatan motif berprestasi siswa yang cukup signifikan dari siklus 1 ke siklus II yaitu sebesar 5,62\%, dapat disimpulkan bahwa layanan konseling kelompok efektif untuk meningkatkan motif berprestasi yang dimiliki siswa dan efektif untuk menumbuhkan keberanian siswa dalam 
mengungkapkan pandangannya dan keinginan siswa untuk berprestasi lebih baik. Sebagai upaya lebih lanjut, pemetaan masalah yang dilakukan konselor harus lebih spesifik, sehingga persoalanpersoalan yang dialami siswa dapat teratasi melalui layanan konseling kelompok. Selain itu peneliti menyarankan kepada beberapa pihak untuk melakukan hal-hal berikut: 1) Untuk Guru BK hendaknya Layanan konseling kelompok yang diberikan memperhatikan alokasi waktu, sehingga siswa lebih antusias ketika mengikuti kegiatan. Selain itu, perlu dilakukan pula inovasi-inovasi layanan bimbingan dan konseling dalam kaitannya dengan pemberian layanan, agar tujuan yang telah dirancang dapat tercapai secara maksimal. 2) Untuk sekolah hendaknya meningkatkan fasilitasfasilitas yang dapat meningkatkan kinerja guru bimbingan dan konseling, seperti memfasilitasi dan mendukung guru BK mengikuti berbagai pelatihan, seminar, dan yang sejenisnya. Hal tersebut semata-mata untuk meningkatkan kompetensi guru bimbingan dan konseling, demi menjaga profesionalitas konselor sekolah.

\section{DAFTAR RUJUKAN}

Arifin, B.S.(2015). Dinamika Kelompok. Bandung: CV Pustaka Setia.

Bashiruddin, A. (2016). Education for Development in Northern Pakistan: Opportunities and Constraints for Rural Households, by Andreas Johannes Benz. South Asia: Journal of South Asian Studies, 39(3), hlm. 709711.

Fiah, R. E \& Anggralisa, I. (2016). Efekitvitas Layanan Konseling Kelompok Dengan Pendekatan Realita Untuk Mengatasi Kesulitan Komunikasi Interpersonal Peserta Didik Kelas X MAN Krui Lampung Barat T.P 2015/2016. Jurnal Bimbingan dan Konseling, 03 (1), hlm. 47-62.

Irham, M dan Wiyani, N, A. (2014). Bimbingan \& Konseling: Teori dan Aplikasi di Sekolah Dasar. Yogyakarta: Ar-Ruzz Media.

Kurnanto, M. E. (2013). Konseling Kelompok. Bandung: Alfabeta.

Makmun, A. S. (2013). Psikologi Kependidikan. Bandung : Rosda.

Muhibbin Syah. (2015). Psikologi Perkembangan. Bandung : Rosda.

Ngalimun. 2014. Bimbingan Konseling di SD / MI Suatu Pendekatan Proses. Yogyakarta: CV. Aswaja Pressindo.

Rusmana, N. (2009).Bimbingan dan Konseling Kelompok di Sekolah: Metode, Teknik, dan Aplikasi. Bandung: Rizqi Press.

Sardiman. (2013). Interaksi dan Motivasi Belajar Mengajar. Jakarta : PT. Raja Grafindo Persada.

Sukardi, Dewa Ketut. 2000. Pengantar Pelaksanaan Program Bimbingan dan Konseling di Sekolah. Jakarta: PT. Rineke Cipta.

Djamarah, S. B. (2012). Psikologi Belajar. Jakarta : Rineka Cipta.

Prayitno, H\& Amti, E. (2004). Dasar-dasar bimbingan dan konseling.Jakarta :Rineka Cipta.

Sari, E, R., Giyono., Shinta Mayasari. (2008). Faktor Penghambat Pelaksanaan Program Bimbingan dan Konseling. Jurnal Bimbingan Konseling. http://jurnal.fkip.unila.ac.id/index.php/ALIB/article/view/2876 diakses: 16 Februari 2015.

Wibowo, M.E. (2005). Konseling kelompok perkembangan. Semarang : UPT UNNES Press

Wikarta, P. V. S. (2016). Pelaksanaan Konselingkelompok Dengan Pendekatan Person-Centered Therapy Dalam Menangani Regulasi Diri Rendah Empat Mahasiswa Angkatan 2014. Jurnal Psiko-Edukasi, 14, hlm. 125-142.

Wulandari, B. (2013). Hambatan Pelaksanaan Layanan Konseling Kelompok pada SMP Negeri se-Kabupaten Wonogiri. Skripsi. Universitas Negeri Semarang. 